Yamanba:

\title{
A Radio Play by Terayama Shuji
}

\section{Erin Lofting}

\begin{abstract}
Terayama Shūji was an important avant-garde Japanese artist and one of the most subversive contributors to Japan's underground theatre movement. Between dropping out of university and forming his theatre troupe, Tenjo Sajiki, Terayama wrote a number of radio plays that helped launch his career as a dramatist. As with his work in other media forms, Terayama's radio plays can provide insight into this fascinating artist's provocative methods and goals. Yamanba appropriates material from Nō theatre and Japanese folklore, and shows Terayama experimenting with representations of cruelty in drama, as described by the French poet and dramatist, Antonin Artaud. Yamanba, first broadcast on NHK Tokyo in 1964 and awarded a prestigious Prix Italia for radio drama that year, is an early version of Terayama's 1971 stage play Heretics, an important work that toured in Europe. Heretics has been published in English translation; this is the first English translation of Yamanba.
\end{abstract}

Key Terms: Terayama Shūji, Terayama Shuji, Yamanba, Heretics, Antonin Artaud, Theatre of cruelty, Angura, Avant-garde, Radio play, Japanese theatre, Japanese folklore, Ubasute, Ubasuteyama.

\section{Introduction}

Terayama Shūji ${ }^{1}$ is one of the most important artists to emerge from Japan in the 1960s. His diverse career includes poetry, journalism, photography, theatre, and film. I first became interested in Terayama in 2005 while living in his home prefecture of Aomori, a mostly rural and comparatively poor area in Northern Japan. I quickly became a regular at Aomori's public library, and enjoyed reading work by local authors. Terayama's stage plays, as presented in Carol Fisher Sorgenfrei's book, Unspeakable Acts: The Avant-Garde Theatre of Terayama Shüji and Postwar Japan fascinated me: they were provocative, disturbing, and richly imaginative. I cannot say that I understood Terayama's creative goals at the time, but I wanted to. I read every English translation of Terayama's work I could find. It did not take long to exhaust this list.

Terayama's life and career also interested me. Many of his contemporaries in the angura ("underground") theatre movement originally formed their troupes as

\footnotetext{
${ }^{1}$ All Japanese names are written with the family name first, as is the custom in Japan.
} 
university drama clubs (Poulton, 2012). Prominent contemporary Japanese dramatists like Betsuyaku Minoru, Ninagawa Yukio, and Suzuki Tadashi all began their careers as part of the angura movement. Terayama was recognized as a gifted poet in his teens, and attended prestigious Waseda University after graduation from high school. However, he soon had to withdraw from university for what became a three-year stay in hospital with a chronic kidney condition (Sorgenfrei, 2005). This led Terayama's career to take a somewhat unusual route. I wanted to better understand how a talented university dropout from Aomori, raised first by a single mother, and then by his greataunt and uncle was able to start his own theatre company in the Shibuya ward of Tokyo. When Dr. Cody Poulton, a professor of Japanese theatre and literature at the University of Victoria, encouraged me to apply for a Jamie Cassels Undergraduate Research Award, I decided to use the opportunity to study Terayama's career between his release from hospital in 1958, and the formation of his theatre troupe, Tenjō Sajiki², in 1967.

Between 1958 and 1966, Terayama wrote children's stories, puppet plays, essays for young people, and radio plays, which were commissioned and broadcast by NHK and RKB, both major radio networks in Japan. Terayama began writing for radio on the advice of his lifelong friend, the renowned poet, Tanikawa Shuntarō (Ridgely, 2010). Although radio broadcasters during this time enjoyed much more freedom than during the war, they also struggled to remain relevant in the age of television. An extraordinary number of television sets were sold in Japan during the late 1950's in anticipation of the live broadcast of Prince Akihito's and Shōda Michiko's wedding (Gordon, 2009). Established radio dramatists and experienced producers also left radio to work in television (Ridgely, 2010). The opportunity for less-experienced writers to be broadcast on the radio, and to be paid well for it, became available as radio competed with television for both audiences and talent (Ridgely, 2010). For Terayama, just released from hospital, the timing could not have been better.

I completed English translations of three of Terayama's radio plays while working on this project: Nakamura Ichirō (1959), Osorezan (1962), and Yamanba (1964), and found interesting connections between these works and Terayama's later stage plays and films. My English translation of Yamanba is published here for the first time and preceded by a summary of the play and a description of my approach to its translation. $^{3}$

\footnotetext{
${ }^{2}$ The name is taken from Marcel Carne's film, Les Enfants du Paradis (Children of Paradise).

${ }^{3}$ Due diligence has been conducted in attempting to locate and request permission from the copyright holder. Reproduced under section 29 of the Canadian Copyright Act: fair dealing.
} 


\section{Yamanba}

It can be difficult to decide which issues to focus on in Terayama's work. His plots are typically labyrinthine, and filled with obscure references and shocking material. Sex and violence are common themes, and his portrayal of mothers is highly critical while fathers are absent or perform insignificant roles. Although it may be tempting to view this as a commentary on the circumstances of Terayama's life, I do not find this approach particularly productive. For Terayama, reality is performative. He advocates freeing theatre from the confines of playhouses as well as actors from their imprisonment within scripts. Reality and drama are inseparable for Terayama, and I believe that looking for elements of Terayama's life in his work is less interesting than observing how his approach to drama is mirrored by how he chose to conduct and represent his life.

Terayama read widely, and was familiar with prominent literary and dramatic figures both within and outside Japan. Antonin Artaud (1896-1948) is an important influence on Terayama's work. Artaud's "theatre of cruelty" demands that dramatic encounters represent the human suffering inevitably incurred though daily existence (Courdy, 2000). Artaud insists that theatre should not be a relaxing, comfortable experience for audiences, and Terayama's confrontational work clearly reflects Artaud's beliefs. Yamanba received a prestigious Prix Italia award for radio plays in 1964, the first year it was broadcast on NHK Tokyo, and is an early version of Terayama's 1971 stage play, Heretics, which toured in Europe to mixed reviews. Many members of the audience in Europe did not appreciate Tenjō Sajiki's metatheatrical antics, and felt that they were simply being harassed (Sorgenfrei, 2005). Yamanba's main character, Heisaku, is an idiot. It is an unusual choice for a radio play, and makes for often difficult listening. The contrast between the poetic language of the Nō chorus, and the old woman who acts as a narrator with Heisaku's stilted speech and limited vocabulary is particularly jarring. Although Artaud's seminal work, The Theatre and its Double, did not appear in Japanese translation until the year after Yamanba was first broadcast (Courdy, 2000), Terayama was wellconnected, and it is reasonable to assume that he knew of Artaud before this book's release. Based on a comparison of Terayama's earlier radio plays and later dramatic work, I believe Yamanba is an early example of Artaud's influence on Terayama.

Heisaku, is not only dim-witted but unattractive and believes he has no chance of marriage. Heisaku's mother, Okuma, tells him he would do better to resign himself to living out his days with her. One day, a Buddhist priest stops Heisaku (who is on route to secretly watch women bathe in a nearby stream), and tells him about a local custom which dictates that any man who reduces the number of mouths to feed in his household by abandoning his mother in the mountains can choose any single woman in the village as his wife. Despite her protests, Heisaku ties up Okuma and leaves her on Ubasuteyama then marries Ayame, the most beautiful woman in town. 
Ayame is furious with Heisaku for choosing her and, in Heisaku's words, married life is "hell." Ayame flaunts her naked body at home, but refuses to let Heisaku to touch her, threatening to kill herself if he comes too near. Desperate, Heisaku returns to Ubasuteyama to ask for his mother's advice. Okuma promises to help Heisaku with his wife on the condition that she is taken home, hidden, and regularly brought food. When Ayame's lover visits the house one afternoon, Heisaku's mother reveals her hiding place beneath the floorboards, and loudly exposes their tryst. Heisaku arrives, attacks Ayame and her lover, and then tears the house apart in a rage while Okuma cheers him on.

Ultimately, it is decreed that Heisaku violated tradition by rescuing his mother, and he must abandon her for a second time. Ayame begrudgingly continues living with Heisaku, although there is no indication that their relationship improves. Yamanba ends with a description of Heisaku, still lonely, wondering what became of his mother.

Yamanba borrows lines from Nō plays, and appropriates Japanese folklore. Ubasuteyama in Nagano Prefecture is steeped in bleak legends about ageing parents abandoned by their impoverished, hungry children. In other works, Terayama tends to borrow from folklore specific to Aomori Prefecture, particularly the legends surrounding Osorezan, a mountain on the Shimokita Peninsula said to be hell on earth. My interest in Aomori's folklore is often helpful toward understanding Terayama's work, but Yamanba necessitated research on the folklore of Nagano Prefecture in central Japan. I relied on Dr. Poulton's expertise to identify passages Terayama pulled from Nō theatre. This translation includes notes where Terayama borrows from outside sources, although I expect there are more references to work outside Yamanba beyond those I identified.

In the interest of consistency, I borrow translations of two poems from Steven C. Ridgely's book, Japanese Counterculture: The Antiestablishment Art of Terayama Shij $i$. These poems are part of a larger cycle of tanka poetry, and also appear in the opening scene of Terayama's 1974 film Den'en ni Shisu (variously translated as: Pastoral: To Die in the Country, Pastoral Hide and Seek, and Cache-Cache Pastoral). I use Yamanba's script as it appears in The Collected Works of Terayama Shüji Vol.2 (寺山修司著作集弟 2 券), and the recording produced by NHK and distributed by King Records. Where the recording and script differ, I translate Yamanba as it is written in Terayama's script. However, Japanese names often have several potential readings, and names appear as they are pronounced in NHK's recording.

Already an established poet, Terayama's radio plays helped him build a reputation as a dramatist, and secure resources and connections that helped him start Tenjō Sajiki. He won several prestigious awards for radio plays, worked with acclaimed producers and composers, and his work was frequently aired in 1966, as 
plans for Tenjō Sajiki began to fall into place (Sorgenfrei, 2005). This translation of Yamanba furthers the opportunity for non-Japanese speaking audiences to study and enjoy an important and influential avant-garde artist. Terayama's early radio plays experiment with techniques, such as pastiche and representations of cruelty, which Terayama continued to use throughout his career. He appropriates from earlier tanka poetry for Yamanba, and then borrows from Yamanba in his later stage play, Heretics, and film, Den'en ni Shisu. Ultimately, however, my study of Terayama's radio plays invites more new questions than it answers. Just as Sorgenfrei expressed hope that her book would promote interest in Terayama, I hope this translation helps facilitate further study.

\section{Translation of Yamanba}

\section{OLD WOMAN $^{4}$}

\section{OKUMA-Baba}

\section{Fukurō-no HEISAKU}

Village banker SAOJŪ

Village jeweller GONJŪ

Wife AYAME

AYAME'S MOTHER

BUDDHIST PRIEST

DYING AGED MOTHER

Secret Paramour SEIBEI

$-1-$

(The voices of NŌ CHORUS become audible suddenly through the darkness, mixed with the sound of wind blowing across a mountain...)

NŌ CHORUS - Looking at the moonlight

Shining on Sarashina ${ }^{5}$ and Ubasuteyama ${ }^{6}$

\footnotetext{
${ }^{4}$ Terayama indicates this character should perform in the style of kyōgen, a farcical comedy act performed alone, or between acts of a Nō play. All footnotes added by the translator.
} 
I could not find comfort for my heart ${ }^{7}$

Following the steps of the poet who wrote this

To the foot of this old tree,

Left buried in dry grass

Little red flowers also bloom out of season ${ }^{8}$

Little red flowers also bloom out of season

(From the bottom of a deep valley, projecting his voice like NŌ CHORUS, a man's voice yells)

VOICE - Mother! Mother!

(Theme music builds, the title overtop)

$-2-$

(A bird hooting, once or twice at a time, a biwa performs lonely-sounding lullabies, $\left.B G^{9}\right)$

OLD WOMAN - (Begins like a kyōgen, becoming contemplative, recites two poems ${ }^{10}$ in a low voice)

Carpenter Town, Temple Town, Rice Town, Buddha Town, The Town for Buying

Old Mothers-

Dear Sparrow, are there not such places?

\footnotetext{
${ }^{5}$ A district of Nagano Prefecture, also the setting of the Nō plays, Yamanba (written by Zeami) and Ubasute.

${ }^{6}$ The common name for Kamurikiyama in Nagano Prefecture, south of Sarashina. Literally, "the mountain for abandoning old mothers". Although it is believed that this did sometimes occur during times of famine, the pratice seems to be disproportionally represented in folklore and literature.

${ }^{7}$ Terayama pulls these three lines from the Nō version of Ubasute, which borrows from an anonymous poem in the Kokinshu.

${ }^{8}$ Terayama is punning, these lines could also be read as a euphemism for someone who is licentious and advanced in age.

${ }^{9}$ Terayama uses BG (background), F.O. (fade out), and F.I. (fade in) as directions.

${ }^{10}$ I borrow translations of these poems from Steven C. Ridgely's Japanese Counterculture: The Antiestablishment Art of Terayama Shūji.
} 
He went out to buy a new butsudan ${ }^{11}$ and never came back-

My missing brother and a bird

OLD WOMAN - (A gust of wind, blowing too hard) This story is from the days

when, in the village at the foot of Sarashina, the practice of abandoning old women was still being observed.

A Buddhist rosary, braided from white hair, floats in the mountain lake, while crows gather in the old tree, and relate the news from hell.

The moon rises brightly over the bald mountain. Does this explain the legend that yamanba ${ }^{12}$ carry the moon as a mirror for applying makeup?

In the village, the promise that someone who reduced the number of mouths to feed in their household by abandoning their ageing mother on Ubasuteyama would receive a wife was duly being upheld, but...

(The biwa playing lullabies suddenly stops, as if a string had snapped, the sound of birds chirping on a clear morning fills the speakers, loggers chopping down a tree, intermittent like slaps on a hand drum)

SAOJŪ - (Like a kyōgen) Did you hear, Gonjū?

GONJŪ - (Like a kyōgen) What's that, Saojū?

SAOJŪ - The owl ${ }^{13}$.

GONJŪ - An owl?

SAOJŪ - The story about when Heisaku cried...

GONJŪ - (Stifling laughter) That idiot, why'd he cry this time?

\footnotetext{
${ }_{11}^{11}$ A Buddhist family altar, honouring ancestors.

${ }^{12}$ A monstrous mountain crone well-known in Japanese folklore. Yamanba are typically represented wearing tattered, filthy kimonos, and having long white hair and cannibalistic tendencies.

${ }^{13}$ Fukurō is written in hiragana letters here. Terayama is punning with "owl/fukurō" (鳥) and “mother/o-fukuro" (袋) here, and throughout this play.
} 
SAOJU - He clung to his mother the night the crows cawed and cried, "I want a wife."

GONJŪ - Even the seven autumn plants ${ }^{14}$ and $J_{i z o}{ }^{15}$ feel amorous this fall.

SAOJŪ - (Laughing) It isn’t unreasonable?

GONJŪ - (Laughing) It isn't unreasonable.

SAOJŪ - He'll never get a wife with his mother there. He can't begin to think about getting a wife before reducing the number of mouths to feed.

GONJŪ - (Replying perfunctorily) That's right.

SAOJŪ - That said, instead of crying and pleading to his mother, taking her to

Ubasuteyama is the easiest way to get what he wants. But she's a wily one,

OKUMA - You expect to get a woman here! There's no one, anywhere, who'd want to spend the night with an idiot like you!

SAOJŪ - ...she snarled. On top of that,

OKUMA - You have an owl instead of a wife. In these times of hardship you, me, and the owl, just us three - after living together so long, why should you feel unsatisfied?

SAOJŪ - ...she coaxed him.

GONJŪ - Heisaku's a mama's boy...

SAOJŪ - She thought she'd put an end to the matter... Then one night...

\footnotetext{
${ }^{14}$ The seven plants of autumn (mirrored by the seven plants of spring) appeared as a poetic motif as early as the Manyōsh $\bar{u}$. The autumn plants are: bush clover, pampas grass, arrowroot, pinks, valerian, boneset, and balloon flower.

${ }^{15}$ A beloved figure in Japanese Buddhism, Jizō is the protector of travelers and children.
} 
(Music bridges, HEISAKU's owl hooting, the shallows of a stream at night, suddenly a splash, HEISAKU crossing the stream... the village's BUDDHIST PRIEST calls out to HEISAKU)

BUDDHIST PRIEST - (From far away) Hey! You there, aren't you Fukurō-no Heisaku?

HEISAKU - Ah, the priest.

(HEISAKU's owl hoots)

BUDDHIST PRIEST - Where are you going across the stream, clutching your owl this late at night...?

HEISAKU - (Laughing stupidly)

BUDDHIST PRIEST - Are you going to Yotsu-no Tani?

HEISAKU - (Still laughing)

BUDDHIST MONK - Well, you're obviously not going trout fishing.

HEISAKU - I'm going to go watch the girls.

BUDDHIST PRIEST - What?

HEISAKU - I'm going to watch the girls bathing in the stream by Yotsu-no Tani. BUDDHIST PRIEST - (Astonished) That's awful.

HEISAKU - They're so beautiful! Watching them rinse their white, naked bodies in the night makes my face feel hot.

BUDDHIST PRIEST - (Reprovingly) How can you, a grown man thirty years old, be so terrible? Go home. Just go home.

HEISAKU - (Not listening) I'm going to watch the girls.

BUDDHIST PRIEST - I already told you to give it up. Don't be immoral. Go home. 
(HEISAKU's owl hoots)

HEISAKU - I'll be off now.

(HEISAKU starts walking, the BUDDHIST PRIEST blocks his path)

BUDDHIST PRIEST - But I already told you to go home.

HEISAKU - Get the hell outta my way! Damn priest!

(Pushes the BUDDHIST PRIEST)

BUDDHIST PRIEST - Hey, what are you doing! (Said angrily, a splash as the PRIEST falls in the stream, the sound of running water) ... Oh, they say fools don't know their own stupidity.

(Water dripping as the BUDDHIST PRIEST stands up)

BUDDHIST PRIEST - (To HEISAKU) If you're feeling so amorous, why don't you get a wife?

HEISAKU - That's no good.

BUDDHIST PRIEST - Why's that?

HEISAKU - My mother says no one's dumb enough to marry me...

BUDDHIST PRIEST - Your mother? (Laughing) That's not the case at all, Heisaku.

In this village, any man can have a wife. If you do things in order, you can choose any girl to go to bed with as your wife.

HEISAKU - What do you mean by doing things in order?

BUDDHIST PRIEST - By reducing the number of mouths to feed, of course.

HEISAKU - Reducing the number of mouths to feed?

BUDDHIST PRIEST - Yes, that's right.

HEISAKU - What should I do? 
BUDDHIST PRIEST - You need to get rid of your mother's mouth. In other words... (The BUDDHIST PRIEST whispers in HEISAKU's ear, it's like a prophesy) if you want a wife, you should take your mother to Ubasuteyama, and leave her there! (A hand drum being played) $-3-$

NŌ CHORUS - The kite strikes the mountain gong

Where is Ubasuteyama?

I shall befriend the moon

Passing the short night

On a pillow made of grass

Viewing various dreams

(A biwa plays lonely-sounding lullabies, a bird hooting, once or twice at a time) OLD WOMAN - Now knowing that it was within his power to get a wife, Heisaku sprang into action. In honesty, he was so ugly that even the crows would laugh. His neck was as thick as a keyaki tree ${ }^{16}$, his eyes bulged out like a fish's, his nose looked like a shihtzu's, and his entire body was covered in course hair. He was dim-witted, and his mouth was always hanging just a little bit open, as though he was about to laugh.

Heisaku had a pet owl, and looked after it with doting care. Though he sometimes forgot to fill his own belly, his love for the owl was blind, and he never failed to gather some nuts for his beloved pet...

\footnotetext{
${ }^{16}$ Zelkova serrata, native to Japan, Korea, China, and Taiwan. A deciduous tree that grows to about $30 \mathrm{~m}$ tall, though also used in bonsai.
} 
(A crowd of villagers beating gongs and drums, cheering voices coming closer, things like "Heisaku's going to dump his mother," "Heisaku's going to get a wife," can be heard amidst the commotion, the crowd is lively but somehow uncanny and upsetting) OLD WOMAN - Heisaku, too, was thinking about the arrival of his wife, and resolved himself to getting rid of his mother. Amongst the single women in town, the prettiest of them all was named Ayame. And, dim though he was, Heisaku captured his mother. (HEISAKU and OKUMA fighting ferociously, far away the sound of the villagers chattering, and beating gongs and taiko drums)

OKUMA - Help me. Please help me!

HEISAKU - Just relax, I'm not letting you go.

OKUMA - You intend to abandon your own mother? The woman who gave birth to you?

HEISAKU - It can't be helped. Hmmf! (HEISAKU lifts OKUMA)

OKUMA - Hiyaa !

HEISAKU - One less mouth to feed, you're just going to have to put up with it! OKUMA - So you're going to tie up the woman who gave birth to you with a red $o b i$ and stuff her into an old sack?

HEISAKU - I'm getting a wife. There's no way around this. Hmmf! Mrrgh!

OKUMA - Ouch, ouch, it's hurting my hips. Loosen it just a little.

HEISAKU - Mrrgh! (The sack drops with a thud) There, how's that?

OKUMA - You're acting like a dog in a dogfight, Heisaku. 
HEISAKU - It can't be helped. Please forgive me. It's something everyone has to do! (The gate opens and the sound of the villagers gathered outside becomes louder, "Ah, she's tied up," "He's strong for a moron," "What on earth," a woman's laughter, the sound of beating gongs and taiko drums, "Look, look," "He's going up the mountain," voices $O F F$, turtledoves cooing, lullaby theme starts again, slow and enveloping, $B G)$

HEISAKU - (Gasping for air) This mountain path is tough going. OKUMA - ... HEISAKU - Ubasuteyama sure is far. OKUMA - (A desperate scheme) Oh no, Heisaku. I've forgotten something. HEISAKU - What's that? OKUMA - Our ancestor's butsudan, of course! I have to keep it polished, and shining like a mirror.

HEISAKU - Don't worry about it. I'll bring it to you here later.

OKUMA - You're going to bring it to me?

HEISAKU - Yes, I'll bring it and an amaryllis to put inside.

OKUMA - (Again) Oh no, Heisaku. I've forgotten something else. HEISAKU - What now?

OKUMA - I saved up some money for you and buried in my purse someplace. I'm the only person who knows where it's buried.

HEISAKU - That's fine. I don't want money. I want a wife. (Still carrying OKUMA on his back, he starts singing ad lib) 
Three $r i^{17}$ to Ubasuteyama

Crows caw and caw nen-neko-sho

My mother on my back

And I both cry

Three ri to Ubasuteyama

Recite the evening prayer, nen-neko-sho

With the red sunset

Namu amida-butsu ${ }^{18}$

OKUMA - (This time speaking sweetly) Oh Heisaku.

HEISAKU - What?

OKUMA - It wasn't all hard times. We had good days too, didn't we?

HEISAKU - ...

OKUMA - I have no regrets. (Sniffling hard) Do you have any complaints about me as a mother?

HEISAKU - None.

OKUMA - In that case, why?

HEISAKU - You mean, why am I dumping you?

OKUMA - Yes.

HEISAKU - I have to get rid of your mouth in order to open my wife's... (The sack

drops with a thud) This is Ubasute-no Tsukimi ${ }^{19}$.

(The murder of crows living on Ubasuteyama caw)

\footnotetext{
${ }^{17}$ One $r i$ is about $3.93 \mathrm{~km}$.

${ }^{18}$ A prayer to Amida Buddha.

${ }^{19}$ Ubasute-no-tsukimiba (姥捨の月見場) implies that this location may be a spot for moon-viewing, a popular activity in autumn, though I am unable to confirm this, or its exact location.
} 
OKUMA - (Bursts into tears) No, no.

HEISAKU - This is where I'm leaving you, mother. I'm not untying the obi so you can't follow me back.

OKUMA - (Crying)

HEISAKU - Mother, I have to get ready to marry Ayame from Hashige, so I'll be going now. (The sound of running, becoming further away) Good bye! (Yelling) Take care!

OKUMA - (Stops crying and becomes completely furious) Idiot! Ungrateful wretch! Fall down a hill and die!

("Die..." echoes down the mountain, the sound of an ominous number of crows cawing and flapping their wings, as if they are preparing to attack OKUMA, music bridges, the sound of a water wheel turning)

AYAME - Disgusting, disgusting. Being married to that idiot is worse than death. My nose will be filled with his stench from now on.

AYAME'S MOTHER - But Ayame, it's all a matter of course, it can't be helped. AYAME - I didn't comb my long, black hair for that idiot. My white breasts didn't swell to be given to him. And most importantly, mother, I detest owls. AYAME'S MOTHER - You'll learn to love what you hate. This is a wife's duty. AYAME - Disgusting, disgusting. It's better to die than become that idiot's wife. I'd rather you dig a grave in the land of the dead and bury my wedding dress.

AYAME'S MOTHER - (Sternly) There's no reasoning with you, Ayame. There's no point in making a fuss, you're soon to be Heisaku's bride. Our household needs to reduce the number of mouths too! 
AYAME - (As though laying a curse) Fine! But even if I'm his wife, I'll never let that moron set a single finger on me!

(Beating on a taiko drum)

$-4-$

NŌ CHORUS - Tipping the sake cask

Arranging blood-colored flowers

I have wed my dream woman

I have wed my dream woman

Let us drink and forget the moon

Shining on Ubasuteyama

(The NŌ CHORUS exposed to strong, cold winds, no more birds hooting, a biwa sloppily plays lullabies)

OLD WOMAN - Anyway, the wedding party went smoothly. In the village, plagued by poor harvests, it was a relief to Ayame's family to have one less mouth to feed, and Heisaku was overjoyed to receive his dream woman...

But the new bride showed absolutely no sign that she was going to forgive Heisaku. He quietly sidled up next to Ayame's bed in the middle of the night, longing to hold that blossom-like body, and was shocked by what he found.

To protect herself, Ayame was sleeping holding a scythe.

Besides that, "Namu amida butsu" was written over her entire nightgown as a charm to protect her!

(The sound of a biwa dropping and smashing, the wind blows for a while...) 
And so, Heisaku didn't set a finger on Ayame on their wedding night. Instead, he slept holding his owl as usual...

(Children sing schoolyard chants, "Which child wants a nagamochi ${ }^{20}$ ? Ayame does.

Rock-scissors-paper, one-two-three. Delighted to lose, covered in flowers. Cursed to win, covered in flowers, " heard from far away, $B G$ )

HEISAKU - Hey, Ayame.

AYAME - ...

HEISAKU - Ayame, what's wrong?

AYAME - ...

HEISAKU - I stoked the fire and made dinner. It's getting cold.

AYAME - ...

HEISAKU - I made pheasant egg soup... And I swept the living room...

AYAME - ...

HEISAKU - You're my wife. Tell me, what's wrong?

AYAME - ...

HEISAKU - Are you so happy that you're speechless?

AYAME - You stink.

HEISAKU - Huh? What?

AYAME - I hate you because you stink.

HEISAKU - Don't say that... (Sidles up to AYAME) Don't say that sort of thing.

AYAME - I hate you. Don't come anywhere near me.

(The owl hoots vacantly)

\footnotetext{
${ }^{20}$ Similar to a hope chest.
} 
HEISAKU - You say you hate me, so I'll just have to wait until you love me. But it's strange that Ayame doesn't feel the same way I do, don't you think, owl? (The owl hoots as if replying)

I just don't understand... I can't put a finger anywhere on my own wife. Is this how the head of a household should be treated?

(The owl hoots sympathetically)

It's like living in hell. This is hell. (Cries)

(The music bridges, a hand drum plays between SAOJŪ and GONJU's lines)

SAOJŪ - (In the style of kyōgen) Did you hear, Gonjū?

GONJŪ - (In the style of kyōgen) What's that, Saojū?

SAOJŪ - The owl.

GONJŪ - The owl?

SAOJŪ - The story about when Heisaku cried...

GONJŪ - (Stifling laughter) That idiot, what'd he cry this time?

SAOJŪ - He wasn't allowed to put a finger on his wife and cried, 'I'm lonely, I'm lonely."

GONJŪ - A stupid thirty-year-old man crying.

SAOJŪ - I just can’t sympathize...

GONJŪ - It's a crazy case of

SAOJŪ - Beauty and the beast.

GONJŪ - Worse yet, she's tormenting him. For example, she'll take out the basin on a moonlit night, and bathe naked in the living room.

SAOJŪ - And he salivates, and swallows hard, 
GONJŪ - Yes, with big gulps,

SAOJŪ - But if he tries to hold her,

GONJŪ - She holds a scythe to her neck...

SAOJŪ - And says something like

GONJŪ - "If you take one more step, I'll slit my throat and end my life."

SAOJŪ - Beside that, namu amida butsu is written all over her underclothes.

GONJŪ - With Heisaku at a distance,

SAOJŪ - She flaunts her body.

GONJŪ - But Heisaku,

SAOJŪ - Can't even rape Ayame.

GONJŪ - Brute strength,

SAOJŪ - Is no match for the grim reaper.

GONJŪ - Ayame holds back boastful laughter,

SAOJŪ - While Heisaku sits cross-legged and cries...

GONJŪ - Have you ever seen,

SAOJŪ - Such a strange,

GONJŪ - Couple.

(The two laugh, a hand drum plays anxiously, a sōzu ${ }^{21}$ on a cold morning)

HEISAKU - (Monologue) Ah, what a cold morning. Ayame's still asleep again today... How long does she intend to coolly continue sleeping with that scythe? Still foggy on the mountain pass. Selling brooms loses out to the chill, I'll make a fire with

\footnotetext{
${ }^{21}$ A decoration, also known as a shishiodoshi, in some Japanese gardens made of bamboo. Typically, the tube fills with water, tips, hits a stone, and begins to refill.
} 
the brooms I was going to sell. Ah, Ayame... I wonder how long you intend to make me wait.

Would you hate me so much if you understood how I feel? (Crying) Would you hate me as much if I fell out of love and felt the same way as you?

I might be stupid. But although I may be dumb, mother said that I have good qualities too... Yes, mother said, "I know that you can always be relied on." Ah, talking with mother is the best thing to do at times like this. If mother was here, she wouldn't make a fool of me like Ayame saying "You stink, you stink!"

(Like a memory, OKUMA's voice sings a lullaby, echoing like a dream)

Go to sleep

Go to sleep

Little ogre

If you don't sleep,

I'll leave you on the mountain

Hush-a-by hush-a-by

I'll leave you on the mountain

Go to sleep

Go to sleep

Yamatarō

If you don't sleep

I'll transform into a yamanba

Hush-a-by hush-a-by

And eat you 
(One strike on a hand drum)

$-5-$

NŌ CHORUS - Yellow patrinia ${ }^{22}$ past its prime

Straw garments discarded

Ashamed in the light of the moon

Waiting only for the moment of death

Hands bound, her white hair in her mouth

Waiting only for the moment of death

(A shakuhachi ${ }^{23}$ drearily plays a lonely-sounding lullaby, BG)

OLD WOMAN - (Speaking without compassion or pity) Ordinarily, it is said that elderly people abandoned on Ubasuteyama will die on the forty-ninth day. Sitting on a goza mat in the shade cast by boulders, looking down on the uninhabited valley below, and collecting nuts like a monkey, life continues until the forty-ninth day. Praying alone with Buddhist rosary beads, how many days pass no longer matters to the body.

In rare cases, elderly people left on Ubasuteyama continue living as long as ninety days, even with their hands and feet bound with an obi, or thick rope, chanting the nenbutsu without moving. But most die within half that time.

Before they die, no small number of elderly people carve their sons' or daughters' names into the rock using their fingernails, or a stick. It's not a curse, but rather a symbol of their connection, and most die thinking of the very child who abandoned them.

\footnotetext{
${ }^{22}$ Patrinia scabiosaefolia (女郎花) is a flowering bushy plant native to Japan, China, and Korea. Terayama is punning. Jorō (女郎), a term for "prostitute" uses the same kanji characters.

${ }^{23}$ A Japanese flute, traditionally make from bamboo.
} 
After death, they are food for the crows. Because of this, the crows on Ubasuteyama always have a remarkably glossy sheen.

Anyway, Heisaku climbed up the mountain to see his mother one bitterly cold day toward dusk.

(Sound of cold, ominous wind blowing on Ubasuteyama, an elderly person muttering deeply and powerfully, sounds like a Buddhist prayer, Heisaku calling for his mother in between)

DYING AGED MOTHER - Combed white hair, one comb

Buried on Ubasuteyama

I go toward death without a grave

I accept this fate, and yet

Somehow linger on, like dead grass

Having only just given birth to my son

Having only just finished raising my son

Left on this rocky mountain

To starve to death all alone

You crows must wait

After I'm dead, they'll noisily feast,

I won't mind if they scatter my bones

Just one task in my final hours

This winter will be cold, and so

I'll weave a stomach band for my son

Out of my white hair 
Until I finish this one task

You crows must wait

HEISAKU - (From far away, climbing the mountain and coming closer) Mother!

Mother! (Speaking to himself) I'm sure that it was around here. Mother! Mother!

Mother, where are you?

DYING AGED MOTHER - (Barely audible over the wind, slowly repeats, Heisaku

calling for his mother in between)

Combed white hair, one comb

Buried on Ubasuteyama

I go toward death without a grave

I accept this fate, and yet

Somehow linger on, like dead grass

HEISAKU - (Calling his mother's name while scrambling up the mountain, startled, he's paralyzed) Ah, a corpse!

AGED MOTHER - No, no, I'm not dead yet.

HEISAKU - (Backing away) You scared me... Corpses can speak!

AGED MOTHER - I'm not dead yet, I'm not dead yet.

HEISAKU - The corpse is crying and crawling toward me... Even the crows don't believe it. What do my eyes see?

AGED MOTHER - Ansama, ansama

HEISAKU - Stay still. Please enter Nirvana ${ }^{24}$.

\footnotetext{
${ }^{24}$ I translate as "enter Niravana" based on previous references to Buddhism in this play. Other possible translations include: "enter heaven", "die peacefully", and "become a Buddha" (a euphemism for death).
} 
AGED MOTHER - I'm not dead yet... There's one more thing I have to do. That's why I can't let go.

HEISAKU - (Mumbling to himself) ...I've heard of old people rolled up in goza mats and dumped in the shade rotting alive, and Ive heard of old people walking down to the village at the foot of this bald mountain, but this is the first time I've heard a dead person chanting the nenbutsu. Heaven forbid, Heaven forbid.

AGED MOTHER - Ansama-ya, ansama-ya!

HEISAKU - Hiyaaa! Help me!

(HEISAKU`s screams and crows cawing all at once, the music indicates HEISAKU running away, music bridges, becomes turtledoves cooing, the sound of choked crying, somehow resembling OKUMA)

HEISAKU - (Running to her) Ah, mother!

OKUMA - (Continues crying)

HEISAKU - (Hugging her) I'm scared, I'm scared! (Crying) I just saw a corpse...

OKUMA - What's that? (Surprised and delighted) Heisaku, is it you? You came back for me?

HEISAKU - (Crying) Yes, I came. I wanted to see you before it got dark, Mother, so I ran all three $r i$ to the mountain.

OKUMA - Is it already dusk?

HEISAKU - The moon is out. You can't see the new moon?

OKUMA - I can't see... Everything's become completely dark.

HEISAKU - Don't say such depressing things.

OKUMA - (Crying) 
HEISAKU - Don't say such depressing things. I need your advice. I just don't know what I should do.

OKUMA - Please loosen the rope. (Crying) And help me warm my body up a little. HEISAKU - Mother, your-daughter-in-law won't show me any affection.

OKUMA - (Crying) It hurts, it hurts.

HEISAKU - Oh, here? Should I untie the rope?

OKUMA - (Breathes a sigh of relief) Oh, you saved me.

HEISAKU - Mother! (Sweetly) What should I do?

OKUMA - (Rather sharply) Heisaku! How about the food?

HEISAKU - Food?

OKUMA - (Overbearingly) You didn't bring your mother some rice and a side dish? HEISAKU - (Dejectedly) I didn't think.

OKUMA - (Yelling) You stupid asshole!

HEISAKU - ...

OKUMA - You're so stupid. It's like this every time you try to do something.

HEISAKU - Don’t be angry.

OKUMA - Heisaku, I'm not like other people my age. I'm not one to fall down the mountain and become food for crows, or crawl around like a crab crying the nenbutsu.

HEISAKU - Huh...

OKUMA - There's no one as tough as me. I'll go on living, and living, and become a yamanba.

HEISAKU - You'll become a yamanba? 
OKUMA - That's right. I'll become a yamanba, and have an odd and interesting life, humming all the while.

HEISAKU - And if there's nothing to eat?

OKUMA - In that case, I'll eat people.

HEISAKU - (Becoming uneasy) Mother!

OKUMA - So, no matter how many times you abandon me, I'll be fine. I haven't weakened in the least!

HEISAKU - I've become weaker than you are.

OKUMA - Of course, I put a curse on you.

HEISAKU - (Starts crying) What should I do? What should I do?

OKUMA - (Calmly) Heisaku!

HEISAKU - Yes?

OKUMA - Take me back home with you.

HEISAKU - But, if I do that...

OKUMA - What's the problem?

HEISAKU - The villagers.

OKUMA - I'll stay under the floorboards where no one will see me, or hide inside the nagamochi. If you keep bringing me food, I'll help you with my daughter-in-law. HEISAKU - You'll teach me?

OKUMA - Yes, I'll teach you.

HEISAKU - (Joyfully) Alright then, let's go home! (Suddenly lifts her onto his shoulders) Hmmf! (One strike on the hand drum, like a wooden clapper) Once I get you home, you can lend me a hand with Ayame. 
OKUMA - Of course, of course. I'll give you a hand.

HEISAKU - (Singing as when he brought OKUMA to the mountain on his back)

Three $r i$ to Ubasuteyama

Crows caw and caw nen-neko-sho

My mother on my back

And I both cry

(A big gust of wind!)

Three ri to Ubasuteyama

Recite the evening prayer, nen-neko-sho

With the red sunset

Namu amida-butsu

$-6-$

NŌ CHORUS - In far away Sarashina,

Near Ubasuteyama

As the pure light of the full moon

On a cloudless night

Slowly leaves the straits,

How it fills me with longing! $!^{25}$

Who's knocking at the back gate?

Someone to hear your sins, or just the mountain wind?

Someone to hear your sins, or just a lost traveler ${ }^{26}$ ?

(Bird hooting, once or twice at a time, the same as before, a biwa plays again)

${ }^{25}$ Terayama pulls these lines from the Nō play Ubasute.

${ }^{26}$ These lines, written in classical Japanese, are vague and difficult to understand. It is unclear if the intent is to accuse, or facilitate confession. 
OLD WOMAN - Heisaku took Okuma home, laid a goza mat out under the floorboards, and kept her there in darkness like the Buddha. Ayame remained, as ever, body and soul unwilling to forgive Heisaku, but Okuma told him to be patient. So, every morning, Heisaku meekly went to work in the fields with his owl perched on his shoulder while Okuma spied on Ayame through a knothole in the floorboards...

(Music stops)

Now this is awkward. It seems as though Ayame has another man.

(The sound of fingertips tapping on a wooden door)

AYAME - (Her voice lowered) Is it you?

VOICE - (His voice lowered) It's me. It's Seibei.

(Sound of the wooden door opening)

SEIBEI - The idiot?

AYAME - He's out.

SEIBEI - There's no one here?

AYAME - No one.

(The door closes, signs they are embracing)

SEIBEI - I missed you, Ayame. I couldn't sleep a wink all last night. Knowing that you're here being held by that moron, and that I couldn't show you my affection tortured my slumber.

AYAME - That's why I slept holding a yellow rose.

SEIBEI - Ah, why did you do that? 
AYAME - You know. My cheeks were sore from your rough beard when I went to sleep the other night. Thinking of you, I woke up, but there was no one else in the room. I could see yellow roses outside through a crack in the door. Ha, ha, my heart doesn't live here, it's in your bedroom. I fell asleep thinking of you, surrounded by the scent of yellow roses.

OKUMA - Bitch. Just as I though, she's taken a lover. So Heisaku's being deceived, and she's taking advantage of his stupidity.

SEIBEI - (While holding her) Ah, to be so in love, and yet,

AYAME - Not to be together.

SEIBEI - They say it's a custom in this village,

AYAME - But to be married to such an ugly moron,

SEIBEI - I don't know who arranged it.

AYAME - A sad story.

SEIBEI - Ayame!

AYAME - Sei-san!

(They embrace strongly, signs they are kissing)

OKUMA - I can't take it anymore (The sound of OKUMA prying loose the floorboards and yelling) Adulterers! Adulterers! Everyone, come here! (Banging on a pot) They're carrying on an affair in the living room. Laughing while they take advantage of my innocent son. Dammit! Adulterers! Adulterers!

(On top of OKUMA's yelling)

SEIBEI - (Flustered $) \mathrm{Ah}$, is it a ghost?

AYAME - She's escaped from Ubasuteyama... 
SEIBEI - She's alive... She's alive!

OKUMA - (Beating the pot and yelling as if she wouldn't notice if the house was on fire) Adulterers! Adulterers! This is hell! Everyone, come here!

(The sound of the pot being beaten, their flustered voices mixing like a whirlpool, cacophonous music blending harshly, HEISAKU arrives breathless, the sound of the shōji tearing)

HEISAKU - Dammit! Dammit!

(The shōji falls over)

SEIBEI - Help me! Help me!

HEISAKU - You sneak in here like a thief while I'm out... Dammit!

SEIBEI - Ah.

(The pot falls over)

OKUMA - Ha ha ha, the pot fell over. That's good, that's good.

HEISAKU - I'll kill you!

(The butsudan falls over)

OKUMA - You broke the butsudan, ah ha ha.

SEIBEI - Ah, help me. It, it hurts.

HEISAKU - Take this!

(Punches him)

AYAME - Hiyaa!

(Ashes thrown into the air)

OKUMA - A cloud of ashes. A cloud of ashes. Ah ha ha ha.

HEISAKU - I'll kill you. 
(Punches him again)

OKUMA - (Roaring with laughter) Yes, yes... You should kill him. (Again, uproarious laughter)

AYAME - Help, help.

HEISAKU - This man was touching your body while I, the head of this household, wasn't allowed.

(Something breaking)

OKUMA - Yes, do it. Do it. Ah ha ha ha ha.

SEIBEI - It, it hurts.

HEISAKU - Die.

(Again, something heavy falls and breaks, only the sound of OKUMA's shrill laughter remains, becomes solitary-sounding, the wind blows, a biwa slowly plays a lullaby) OLD WOMAN - Okuma fell over laughing, while the idiot Heisaku, who'd hit his wife and her lover with a log, cried big, heavy tears. Without fixing the hem of her kimono Ayame ran after Seibei, who was covered in blood. Heisaku called out and cried. A representative of the village came to settle the matter, and decreed that it was wrong for Heisaku to bring his mother back from Ubasuteyama, and that he had to put her back there.

(From far away, the villagers beating a gong, coming closer)

In a poor village, there are famines when the population increases. Of course, reducing the number of mouths to feed only means they'll be replaced with new mouths. 
Heisaku told Okuma what he'd been told. And Okuma meekly let him speak. Perhaps she already intended to die on the mountain alone.

(At the same time, villagers beating a gong, coming closer)

HEISAKU - Mother! I won't fail to visit you.

OLD WOMAN - The idiot said. Okuma pressed her face into her son's back until it hurt and said nothing.

HEISAKU - (Singing sonorously)

Three $r i$ to Ubasuteyama

Crows caw and caw nen-neko-sho

My mother on my back

And I both cry

OKUMA - Heisaku, don't be fooled by your next girl.

HEISAKU $-\mathrm{Ok} .$.

OKUMA - You're an idiot, so it's easier for people to fool you.

HEISAKU - Ok...!

OKUMA - Well, if you're going to sing, why not sing as though you mean it! Your mother becoming a yamanba is a day to celebrate.

HEISAKU - Alright, I'll sing. (Sounding as though he's crying)

Three $r$ to Ubasuteyama

Recite the evening prayer, nen-neko-sho

With the red sunset

Namu amida-butsu

(Again, crows cawing on Ubasuteyama... music plays) 
(Birds hooting, one or twice at a time, a shakuhachi and a biwa play a lonelysounding lullaby, $B G)$

OLD WOMAN - Several years passed... Ayame and her ex, Heisaku, were living together with his owl. Forty years passed but, sitting cross-legged he'd still say, 'I'm lonely, I'm lonely" and cry from time to time.

Sometimes there'd be a knock at the door in the middle of the night.

"Mother?" he'd say, and rush out of bed to answer, but it would only be the wind blowing down from the mountain.

Perhaps his mother was already dead. But Heisaku felt sure she was still hiding on Ubasuteyama.

If she'd become a yamanba, what a strange and interesting life she must have, he thought.

Although he'd meant to, he never went to visit his mother.

And so, there was no grave for Okuma on Ubasetuyama. People who live in hiding don't need graves.

(A lullaby, the sound of the wind blowing, becoming louder, and then fading to nothing)

\section{References}

Courdy, K. (2000). Antonin Artaud's Influence on Terayama Shuji. In Stanca ScholzCionca and Samuel L. Leiter (Eds.), Japanese theater and the international stage (pp. 255-268). Leiden, Netherlands: Brill.

Gordon, A. (2009). A modern history of Japan: From Tokugawa time to the present. $2^{\text {nd }}$ edition. New York and Oxford: Oxford University Press.

Poulton, M. C. (2012, March). “Angura: The 1960s Reaction Against Shingeki Realism." PAAS 486 Class. Lecture conducted at the University of Victoria, Victoria, BC. 
Ridgely, S. C. (2010). Japanese counterculture: The antiestablishment art of Terayama Shuji. Minneapolis: Minnesota University Press.

Sorgenfrei, C. F. (2005). Unspeakable acts: The avant-garde theatre of Terayama Shuji and postwar Japan. Honolulu: University of Hawaii Press.

Terayama, S. (1964). [Recorded by NHK]. Yamanba [CD]. Tokyo: King Records. (2005)

Terayama, S. (2009). "Yamanba." In Sasaki Ichitaka (Ed.), The collected works of Terayama Shüji Vol.2 寺山修司著作集弟 2 券 (pp. 75-100). Tokyo: Kuitessensu Publishing.

\section{Contact Information}

Erin Lofting, from the Department of Pacific and Asian Studies, can be reached at erin.lofting@gmail.com.

\section{Acknowledgements}

Thanks to: Dr. Cody Poulton, supervising professor and mentor; Masahide Koyama, and my friends in Aomori Prefecture; the helpful staff at McPherson library, especially Ying Liu; the friends who participated in my game of let's-think-of-bettersynonyms; and support and encouragement from the Jamie Cassels Undergraduate Research Award, an exceptional program administered by the University of Victoria. 